\title{
LA EXPULSIÓN COMO PENA CONTRA UN INMIGRANTE: ¿ES UN CASTIGO O UN PREMIO PARA EL CONDENADO EXTRANJERO SIN RESIDENCIA LEGAL?
}

\author{
Deportation as criminal penalty \\ against an immigrant: Is it a \\ punishment or a reward to the \\ convicted non-resident foreigner?
}

\author{
Carlos GutiérRez Moya* \\ Instituto de Estudios Judiciales "Hernán Correa de la Cerda" \\ Santiago, Chile
}

RESUMEN: La pena sustitutiva de expulsión del territorio nacional a un condenado extranjero que no tiene residencia legal en Chile, está prevista en el artículo 34 de la Ley n 18.216 modificada por la Ley $n^{\circ} 20.603$ de 2012. Es muy difícil de justificar según la doctrina de los fines de la pena. Además, su aplicación ha sido cuestionada desde dos puntos de vista. En primer lugar, sería un privilegio que vulneraría la igualdad ante la ley, como un derecho constitucional de todos y cada uno de los habitantes de la República de Chile. En segundo lugar, porque lesionaría el derecho a la tutela judicial mediante la denegación de justicia a las víctimas de un delito.

Abogado. Licenciado en Ciencias Jurídicas y Sociales, Universidad de Chile. Profesor extraordinario del Instituto de Estudios Judiciales "Hernán Correa de la Cerda". Máster en Responsabilidad Civil, Universidad de Jaén en colaboración con la Universidad de Málaga. Alumno del Programa de Doctorado en Derecho de la Universidad de los Andes, Santiago de Chile. Correo electrónico: <profesorcarlosgutierrez@gmail.com>.

Artículo recibido el 30 de septiembre de 2016 y aceptado para publicación el 30 de diciembre de 2016 
GUTIÉRREZ MOYA, CARLOS: LA EXPULSIÓN COMO PENA CONTRA UN INMIGRANTE: ¿ES UN CASTIGO O UN PREMIO PARA EL CONDENADO EXTRANJERO SIN RESIDENCIA LEGAL?

PALABRAS CLAVE: inmigrante no residente condenado, pena sustitutiva de expulsión, fines de la pena, privilegio, tutela judicial

ABSTRACT: The substitution of punishment by deporting the convicted illegal non-resident foreigner out of Chile, is established in article 34 of the Act $n^{\circ} 18.216$ reformed by Act $n^{\circ} 20.603$ of 2012. It has been very difficult to justify according to the doctrine of the ends of the criminal penalty. Besides, its imposition has been objected from two points of view. First, it could be a privilege inconsistent with equal protection clause, as a constitutional civil right of the people who live in the Republic of Chile. Second, because it could be against due process of law by the denial of justice for the victims of a felony.

KEY WORDS: convicted non-resident immigrant, substitution of deporting criminal penalty, ends of criminal penalty, privilege, equal protection

\section{INTRODUCCIÓN}

Desde tiempos de la Prehistoria, los desplazamientos de grupos humanos han sido fenómenos sociales muy importantes para la humanidad. ${ }^{1}$ Las migraciones han servido para el poblamiento de zonas deshabitadas de nuestro planeta, como lo fue la travesía desde Asia Oriental cruzando el estrecho de Bering hacia América del Norte y la formación de asentamientos que ha permitido el auge de numerosas aldeas, ciudades, naciones y civilizaciones. Los bárbaros invasores, tales como los hunos, godos (visigodos y ostrogodos), francos, suevos, burgundios, vándalos, hérulos, alanos, alamanes y otros, provenientes de Asia y Europa Oriental, provocaron la caída del Imperio Romano en Occidente y forjaron los reinos medievales que se transformaron más adelante en los Estados soberanos de la Europa moderna. Los conquistadores españoles echaron raíces en América del Sur y América Central. Los portugueses colonizaron la Amazona oriental que más tarde se Ilamará Brasil. Los peregrinos ingleses y holandeses que huyeron de las persecuciones religiosas en Europa del siglo XVII, colonizaron los territorios de la costa Atlántica, y se organizaron políticamente en 13 Colonias, expandiéndose hacia la conquista del Oeste, base de los Estados Unidos de América. Otras causas han sido dramáticas o trágicas: miseria, hambre, desempleo, discriminaciones,

Blanc-Chaléard (2000) p. 2; Arango (1995) p 1. 
persecuciones, guerras, dictaduras, calamidades. ${ }^{2}$ Solo a partir del siglo XX algunos países empezaron a controlar los flujos migratorios ${ }^{3}$, con ocasión de los conflictos bélicos y guerras civiles que han generado olas de movimientos migratorios masivos, que los gobiernos no están dispuestos a aceptar con la misma facilidad que antes.

Las fronteras conservan una importancia de talismán en el pensamiento de la seguridad. ${ }^{4}$ El tratado de Amsterdam, que entró en vigor el $1^{\circ}$ de mayo de 1999, incorporó el Convenio de Schengen de 1985 a la Unión Europea. Ha establecido normas y medidas mínimas de control de las fronteras exteriores de la Unión Europea, para el asilo y protección de refugiados, procedimientos y condiciones para el otorgamiento de visas por tres meses o de larga duración por reagrupamiento familiar, para la lucha contra la inmigración clandestina y la permanencia irregular, y un procedimiento de repatriación de los contraventores. ${ }^{5}$ Cuatro ángulos presentan a los inmigrantes como una amenaza. Trabajo: son acusados de acaparar el trabajo de los nacionales o de hacer bajar los salarios; de orden público: que pone acento en la dimensión seguridad ciudadana; el ángulo fiscal: la obligación de contribuir a financiar prestaciones en materia de salud pública y educación; y la cohesión nacional: que asocia las diferencias culturales (tradición, religión e idioma) como una amenaza para la unidad nacional y la armonía social. ${ }^{6}$ Cerca de 40.000 refugiados en Italia y Grecia que arribaron ilegalmente principalmente desde Siria y Eritea, serán reubicados en otros países de la Unión Europea en un plazo de dos años. Se trata del $40 \%$ de los solicitantes de asilo que necesitan protección internacional. Cada Estado miembro deberá asumir una cuota de asilados que será proporcional a su población, desempleo, riqueza y cantidad de refugiados que ya tienen. ${ }^{7}$ La propuesta y las bases de cálculo de las cuotas de refugiados han sido cuestionadas por algunos países de la Unión Europea. En el Reino Unido, la Reina Elizabeth II ha presentado un proyecto al Parlamento británico destinado a disminuir la inmigración ilegal, otorgando poderes a la policía para confiscar los salarios de trabajadores extranjeros indocumentados. Además, será creada una agencia que haga frente a los casos de tráfico de inmigrantes para fines laborales y de explotación de

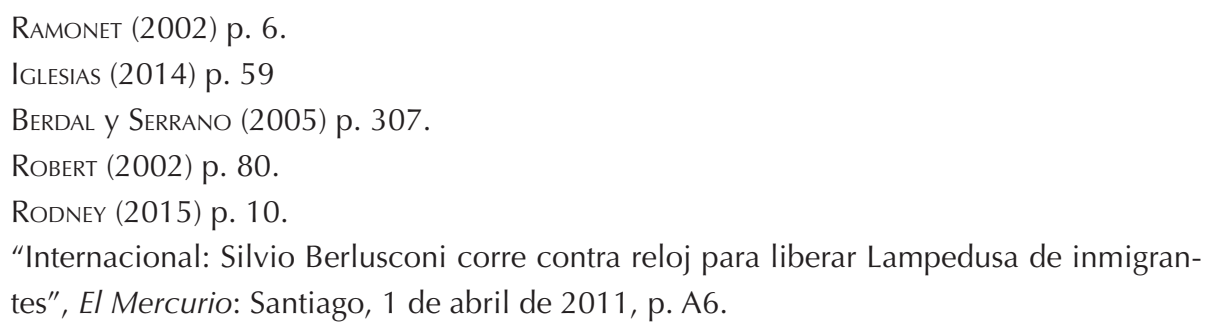


GUTIÉRREZ MOYA, CARLOS: LA EXPULSIÓN COMO PENA CONTRA UN INMIGRANTE: ¿ES UN CASTIGO O UN PREMIO PARA EL CONDENADO EXTRANJERO SIN RESIDENCIA LEGAL?

trabajadores extranjeros. ${ }^{8}$ Estas cifras se dispararon hasta llegar a 103.000 inmigrantes ilegales al 10 de junio de 2015, según la información aportada por un portavoz del Alto Comisionado de las Naciones Unidas para los Refugiados, en su sede de Ginebra. En marzo de 2016, los refugiados en Italia y Grecia aumentaron a más de 160.000, quienes a propuesta de la Canciller alemana Ángela Merkel, el Consejo de Europa ordenó que fueran acogidos obligatoriamente por los Estados de la Unión Europea, sobre la base de un sistema de repartición proporcional. Esta fue una causa de la aprobación por mayoría del pueblo, del referéndum de salida de Gran Bretaña de la Unión Europea, conocido como Brexit.

La Unión Europea ha sido erigida bajo la premisa de la libre circulación de mercaderías, de bienes, de servicios y de personas al interior de las fronteras de los Estados miembros. Sin embargo, en lo concerniente a los extranjeros, impone barreras físicas y legales cada vez más altas a sus fronteras para asegurar sus territorios nacionales, contra los países limítrofes. En este momento se habla de "la forteresse Europe", el proyecto de fortaleza europea que se construye a partir de episodios sobre el arribo de inmigrantes africanos ingresados de manera clandestina. A modo ilustrativo, la playa de Calais en Normandía, Norte de Francia. También en Melilla y Ceuta, enclaves españoles en el Norte de África, que contienen a los marroquíes. En la costa mediterránea de España, frente a la llegada de navegantes africanos en botes Ilamados "pateras", y en la isla Lampedusa al Sur de Italia, contra los libios. ${ }^{10}$ Asimismo, la frontera oriental de Grecia ha sido reforzada para detener a los asiáticos del Medio Oriente que huyen de la guerra civil de Siria y el desplazamiento causado por las conquistas del Estado Islámico (abreviado ISIS en inglés y Daech en francés). Dentro de la Unión Europea, Grecia y Hungría han levantado enormes rejas con alambradas de púas en la frontera con países que han recibido olas de inmigrantes y refugiados.

Los patrones migratorios son explicados por las necesidades de países occidentales de trabajadores inmigrantes y las aspiraciones de éstos a una vida mejor, sobre todo en los países en vías de desarrollo. ${ }^{11}$ La cuestión de los migrantes está siendo utilizada como herramienta política, con fines de cálculos electorales, denunciando al pacto electoral rival como xenófobo y discriminador. A la inversa, la respuesta de éstos es criticar a los adversarios

\footnotetext{
"Unión Europea: 40.000 refugiados". El Mercurio: Santiago, 28 de mayo de 2015, p. A4. ROBERT (2002) p. 75.

"Internacional: Silvio Berlusconi corre contra reloj para liberar Lampedusa de inmigrantes", El Mercurio: Santiago, 1 de abril de 2011, p. A6.

11 MACKENZIE (2005) p. 155.
} 
como facilitadores del crimen organizado transnacional y ser promotores de la delincuencia de bagatela. Algunas personas y partidos políticos, junto con organizaciones pro derechos humanos, son favorables a la inmigración como forma de enriquecer nuestro país con «savia nueva», aportar al desarrollo del país, fortalecer la diversidad religiosa y el pluralismo cultural. El fenómeno migratorio en Chile ha sido aceptado por una razón de necesidad, ya que ha tenido gran importancia para aumentar la densidad poblacional, ante el bajo número de habitantes que pueblan el extenso territorio chileno. Tradicionalmente Chile es considerado como un país acogedor de los inmigrantes. De hecho, nuestra nación se ha formado principalmente de los conquistadores españoles, y más tarde por colonos alemanes, ingleses, italianos, croatas, suizos, sirios y palestinos, que huyeron con sus familias de la devastación causada por las guerras mundiales. Se han integrado al tejido social de manera armónica, aportando sus talentos y sus tecnologías avanzadas.

Desde el año 2010, Chile se ha convertido en uno de los países latinoamericanos con crecientes flujos migratorios, principalmente de peruanos, bolivianos, colombianos y argentinos, a los cuales se suman haitianos y dominicanos. Estas migraciones alcanzan 477.000 extranjeros, según el registro del año 2016 del Departamento de Extranjería y Migración, del Ministerio del Interior y Seguridad Pública. Corresponde apenas al 2,7\% de los habitantes de la República de Chile. En Chile, hoy en día, no hay migraciones masivas y nadie puede oponerse sensatamente a la inmigración en sí misma. Pero como es lógico, hay molestia en la ciudadanía y en las autoridades contra la llegada de extranjeros que tienen el propósito franco y directo de delinquir, en clonación de tarjetas de crédito y débito, préstamo de dinero bajo amenaza, tráfico de migrantes y trata de personas con fines de explotación sexual y laboral, tráfico ilícito de drogas, criminalidad organizada transnacional, etc. Según Rodrigo Sandoval, Director Nacional de Extranjería, "las personas asocian la expulsión con la comisión de un delito. Pero la mayoría de extranjeros son expulsados por haber ingresado clandestinamente. Solo el 3,6 por ciento de los reos que cumplen condena son extranjeros. El 75 por ciento de los inmigrantes asentados en el país proviene de América. 4,7 millones de extranjeros han ingresado a Chile entre enero y septiembre de 2016. Más de 250.000 han permanecido en Chile". ${ }^{12}$

En un Estado constitucional que defiende los valores superiores de libertad e igualdad, la regla general debiera ser permitir el ingreso de los

12 "Jefe de Policía de Investigaciones advierte sobre la vulnerabilidad en aeropuerto Pudahuel del sistema migratorio chileno". El Mercurio: Santiago, 30 de noviembre de 2016, p. C9. 
GUTIÉRREZ MOYA, CARLOS: LA EXPULSIÓN COMO PENA CONTRA UN INMIGRANTE: ¿ES UN CASTIGO O UN PREMIO PARA EL CONDENADO EXTRANJERO SIN RESIDENCIA LEGAL?

inmigrantes, y únicamente de manera excepcional, condicionar o prohibir para casos graves la inmigración. La libertad de toda persona para ingresar al territorio de la República de Chile, puede oponerse a otros derechos o intereses. La inmigración ilegal ha despertado preocupación en la ciudadanía y en las autoridades, sobre las cuestiones humanitarias y de seguridad de la población. Los núcleos problemáticos más relevantes son los extranjeros que perturban el orden público, cometiendo delitos, y la sensación de sobreoferta de mano de obra no calificada, que sería una causa directa del aumento del desempleo en el país. Las respuestas a la cuestión de la inmigración, van desde el control fronterizo hasta la deportación. La deportación o expulsión administrativa es diferente a la pena sustitutiva de expulsión del territorio nacional. El ingreso de extranjeros transeúntes o visitantes es condicionado a una estadía de breve tiempo en nuestro país, y la deportación se llama expulsión del territorio de la República por acto de autoridad administrativa. La deportación es regulada en el Decreto Ley n 1.094 de 1975, que establece normas sobre extranjeros en Chile, más conocido como "Ley de Extranjería". ${ }^{13}$

La hipótesis de trabajo consiste en analizar la operatividad y adecuación de la pena sustitutiva de expulsión, a uno o más fines de la sanción penal. Para lograr este propósito, definiremos la expulsión penal y expondremos su regulación legal. Luego, juzgaremos el impacto que tiene sobre el derecho a la igualdad ante la ley, y en el derecho a la tutela judicial efectiva de la víctima. De lege lata, estudiamos y analizamos la constitucionalidad de la pena sustitutiva de expulsión del territorio de la República, en cuanto a sus fines y su regulación. Asimismo, de lege ferenda, formulamos propuestas y opciones posibles de sanciones más adecuadas a los fines de la pena.

\section{I. ÁMBITO DE APLICACIÓN DE LA EXPULSIÓN PENAL}

\section{Necesidad de la pena sustitutiva}

No es sostenible ni conveniente para la sociedad ni para los condenados, que todos éstos merezcan ir a la cárcel por cualquier delito que hubieren cometido. Con distintos argumentos, los estudiosos del Derecho Penal coinciden en que es necesario que la ley establezca penas sustitutivas a las penas privativas o restrictivas de libertad. Esto es, que frente a determinadas penas privativas de libertad para hechos de poca gravedad no reiterados, la alternativa no sea una medida, sino una pena alternativa o sustitutiva, que por

13 Unidad De Defensa Penal Juvenil Y Defensas Especializadas (2015) p. 3. 
una parte elimina la privación de libertad y por la otra evita todos los posibles efectos colaterales de las medidas. ${ }^{14}$

En Chile, en virtud del artículo $19 \mathrm{n}^{\circ} 7$ de la Constitución Política de la República de 1980, todas las personas, sean chilenos o extranjeros, gozan de libertad ambulatoria o de circulación: "libertad para residir y permanecer en cualquier lugar de la República, trasladarse de uno a otro y entrar y salir de su territorio, a condición de que se guarden las normas establecidas en la ley y salvo siempre el perjuicio de terceros". Con todo, esta libertad de desplazamiento admite restricciones indirectamente constitucionales, sobre la base del principio de legalidad y de reserva de ley en materia penal, y en consecuencia, la expulsión penal es formalmente legítima. Es ajustada a nuestra Constitución.

El artículo $1^{\circ}$ inciso primero de la Ley $\mathrm{n}^{\circ} 18.216$ modificada por la Ley $\mathrm{n}^{\circ}$ 20.603 de 2012, publicada en el Diario Oficial de fecha 27 de junio de 2012, establece un catálogo de penas sustitutivas que el juez o tribunal competente puede imponer al condenado, siempre y cuando se reúnan en el caso concreto todos los requisitos legales previstos para cada pena sustitutiva que será aplicada: "Artículo $1^{\circ}$. La ejecución de las penas privativas o restrictivas de libertad podrán sustituirse por el tribunal que las imponga, por alguna de las siguientes penas: a) Remisión condicional, b) Reclusión parcial, c) Libertad vigilada, d) Libertad vigilada intensiva, e) Expulsión, en el caso señalado en el artículo 34, f) Prestación de servicios en beneficio de la comunidad".

\section{Redacción legal y definición de la expulsión}

La expulsión del territorio nacional está contenida en la Ley $\mathrm{n}^{\circ} 18.216$ modificada por la Ley ${ }^{\circ} 20.603$ de 2012, precisamente en el párrafo $3^{\circ}$ De la regla especial aplicable a los extranjeros:

"Artículo 34. Si el condenado a una pena igual o inferior a cinco años de presidio o reclusión menor en su grado máximo fuere un extranjero que no residiere legalmente en el país, el juez, de oficio o a petición de parte, podrá sustituir el cumplimiento de dicha pena por la expulsión de aquél del territorio nacional.

A la audiencia que tenga por objetivo resolver acerca de la posible sustitución de la pena privativa de libertad por la expulsión del territorio nacional deberá ser citado el Ministerio del Interior y Seguridad

\footnotetext{
$14 \quad$ Bustos (1997) p. 96.
} 
GUTIÉRREZ MOYA, CARLOS: LA EXPULSIÓN COMO PENA CONTRA UN INMIGRANTE: ¿ES UN CASTIGO O UN PREMIO PARA EL CONDENADO EXTRANJERO SIN RESIDENCIA LEGAL?

Pública, a fin de ser oído. Si se ordenare la expulsión, deberá oficiarse al Departamento de Extranjería del Ministerio mencionado para efectos de que lleve a cabo la implementación de esta pena y se ordenará la internación del condenado hasta la ejecución de la misma.

El condenado extranjero al que se le aplica la pena de expulsión no podrá regresar al territorio nacional en un plazo de diez años, contado desde la fecha de la sustitución de la pena.

En caso que el condenado regresare al territorio nacional dentro del plazo señalado en el inciso anterior se revocará la pena de expulsión, debiendo cumplirse el saldo de la pena privativa de libertad originalmente impuesta".

La pena sustitutiva de expulsión es la salida forzosa del territorio nacional, impuesta por un juez o tribunal a un condenado extranjero sin residencia legal en Chile, con prohibición de regresar en un plazo de diez años contado desde la fecha de la sustitución de la pena. ${ }^{15}$ La expulsión penal se encuentra íntegramente vigente desde la fecha de su promulgación, en aquellos aspectos que sean más favorables para los condenados. Esto es válido incluso en los pasajes que requieren de adecuación reglamentaria. La razón es que la Ley $n^{\circ} 20.603$ de 2012 resulta aplicable in actum a contar desde que fue promulgada como ley de la República, de conformidad al artículo $19 \mathrm{n}^{\circ} 3$ inciso penúltimo de la Constitución Política de la República y al artículo 18 del Código Penal. ${ }^{16}$ Es evidente que la pena sustitutiva de expulsión del territorio de la República es más favorable al condenado que la pena de presidio o reclusión de cumplimiento real. La defensa puede solicitar a favor del extranjero condenado a una pena privativa de libertad de cumplimiento efectivo, que se imponga la pena sustitutiva de expulsión del territorio de la República, para que no continúe cumpliendo la pena en la cárcel. El tribunal competente para conocer esta solicitud, es el juez de garantía encargado de la ejecución de la condena que ha sido impuesta.

\section{Improcedencia de la expulsión}

\section{A) Delitos excluidos}

El Artículo $1^{\circ}$ inciso segundo de la Ley $\mathrm{n}^{\circ} 18.216$ modificada por la Ley $\mathrm{n}^{\circ} 20.603$ de 2012, que establece penas que indica como sustitutivas a

15 Hay otra definición similar en Defensoría Penal Pública (2014) p. 150.

16 Corte de Apelaciones de San Miguel, A favor de I.G.G. y O.S.C. (2013, rol n² 295-2013) considerando $7^{\circ}$. 
las penas privativas o restrictivas, ha enumerado un catálogo de delitos que están excluidos en forma expresa de merecer la pena de expulsión, debido a que son considerados especialmente graves por el poder legislativo: "No procederá la facultad establecida en el inciso precedente ni la del artículo 33 de esta ley, tratándose de los autores de los delitos consumados previstos en los artículos 141, incisos tercero, cuarto y quinto; 142, 150 A, 150 B, 361, 362, 372 bis, 390 y 391 del Código Penal; en los artículos 8, 9, 10, 13, 14 y 14 D de la ley $n^{\circ}$ 17.798; de los delitos o cuasidelitos que se cometan empleando alguna de las armas o elementos mencionados en las letras a), b) c), d) y e) del artículo $2^{\circ}$ y en el artículo $3^{\circ}$ de la citada ley $n^{\circ} 17.798$, salvo en los casos en que la determinación de pena se hubiere considerado la circunstancia primera establecida en el artículo 11 del mismo Código".

\section{B) FALTAS}

Según el Código Penal chileno, las faltas no permiten al juez o tribunal imponer penas privativas de libertad de ninguna clase ni temporalidad. Las faltas son castigadas con penas de multa, de naturaleza pecuniaria, o privación de derechos por breve tiempo. Este es un requisito esencial para que pueda operar la sustitución de la pena. Si el imputado es condenado a una pena de multa o a cualquier otra pena no privativa de libertad, jamás podrá aplicarse la expulsión penal a este imputado.

\section{C) ADOLESCENTES INFRACTORES DE LEY}

Tampoco es procedente condenar con la expulsión a los adolescentes extranjeros infractores de ley, a quienes únicamente puede imponerse sanciones establecidas en el artículo $6^{\circ}$ de la Ley $n^{\circ} 20.084$ de Responsabilidad Penal Adolescente. Estas sanciones son internación en régimen cerrado con programa de reinserción social; internación en régimen semicerrado con programa de reinserción social; libertad asistida especial; libertad asistida; prestación de servicios en beneficio de la comunidad; multa; y amonestación. El artículo $7^{\circ}$ de la Ley $n^{\circ} 20.084$ de Responsabilidad Penal Adolescente, faculta al juez a imponer al adolescente la obligación de someterlo a tratamientos de rehabilitación por adicción a las drogas o al alcohol.

\section{D) EXTRANIEROS QUE GOZAN DE INMUNIDAD JURISDICCIONAL PENAL}

De acuerdo con los principios generales de Derecho Internacional Público, los jefes de Estado extranjeros gozan de una amplia inmunidad jurisdiccional civil, penal y tributaria, tanto por hechos ejecutados como persona natural, como por actos cometidos en el ejercicio de sus funciones. La inmunidad de jurisdicción penal concedida a los jefes de Estado se considera 
GUTIÉRREZ MOYA, CARLOS: LA EXPULSIÓN COMO PENA CONTRA UN INMIGRANTE: ¿ES UN CASTIGO O UN PREMIO PARA EL CONDENADO EXTRANJERO SIN RESIDENCIA LEGAL?

absoluta; no se conoce caso alguno en que un Estado haya tratado de ejercer la jurisdicción criminal contra un jefe de Estado o de gobierno visitante ${ }^{17}$. El artículo 29 de la Convención de Viena sobre Relaciones Diplomáticas de 18 de abril de 1961, regula el trato que deben recibir los agentes diplomáticos y consulares extranjeros, preceptúa: "Ningún jefe de Estado, Ministro de Relaciones Exteriores, agente diplomático o consular extranjero podrá ser detenido, procesado criminalmente o condenado por delito". Esta institución conocida como "inmunidad de jurisdicción de los agentes diplomáticos y consulares extranjeros", es consecuencia del principio de soberanía del Estado, ya que son representantes oficiales del Estado. ${ }^{18}$ Estos privilegios e inmunidades garantizan a los agentes diplomáticos y consulares que "no pueden ser objeto de ninguna forma de detención o arresto", salvo situaciones de "detención flagrante" en caso de legítima defensa o estado de necesidad. ${ }^{19}$ Tampoco pueden ser juzgados ni condenados de delitos por un juez o tribunal en el país extranjero donde están ejerciendo actualmente sus funciones diplomáticas o consulares. Son privilegios similares a los que ostentan los jefes de Estado extranjeros.

\section{Regla especial para el delito de usura}

El inciso segundo del artículo 472 del Código Penal, establece una regla especialísima para el extranjero condenado por usura. La conducta típica de este delito es suministrar valores a un interés que exceda el máximo que la ley permite estipular. Según su inciso tercero, éste debe ser expulsado del país, después de cumplida la pena principal. ${ }^{20}$ Tratándose de un nacionalizado reincidente, debe ser cancelada su carta de nacionalidad chilena y ser expulsado del territorio nacional, también después de cumplida la pena. En la actualidad, algunos extranjeros inmigrantes y residentes han sido sorprendidos por la Policía de Investigaciones de Chile implementando el préstamo de dinero informal, Ilamado "gota a gota" o "crediexpress". Los más conocidos a través de las noticias son integrantes de bandas criminales de origen colombiano. Éstos facilitan dinero en efectivo a pequeños comerciantes, sin exigir requisitos de aptitud o solvencia económica, y con posterioridad cobran al deudor la devolución del dinero prestado a tasas de interés de 15\% a 20\% mensual. Ante el no pago oportuno o atraso en el plazo adicional, recurren a las vías de hecho, tales como advertencias fuertes, seguidas de delitos tales como amenazas contra su vida e integridad física, incluyendo lesiones.

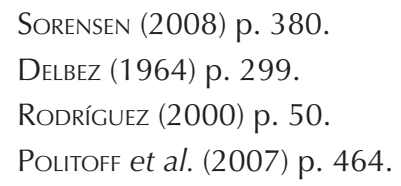




\section{Límite temporal de la pena privativa de libertad que puede ser sustitui- da por la expulsión}

La posibilidad de sustituir la pena privativa de libertad por la expulsión penal se refiere a un límite máximo de cinco años de presidio o reclusión menor en su grado mínimo, de duración de aquella. En el extremo inferior, no existe un límite mínimo de la pena. Podría aplicarse por el juez la expulsión penal a un condenado extranjero por simple delito inferior a un año, sin ilegitimidad formal alguna. Por ejemplo, un día de prisión en su grado mínimo.

En España, la Ley 1/2015 de 30 de marzo, introdujo cambios en el artículo 89 del Código Penal, que consisten en que solo podrán sustituirse "las penas de prisión de más de un año impuestas", lo que ha supuesto una reducción del ámbito objetivo del precepto. ${ }^{21}$ Además, se generaliza la expulsión a todos los "ciudadanos extranjeros". En consecuencia, también a los extranjeros residentes legalmente en España y a los ciudadanos de la Unión Europea, aun con las limitaciones que el propio precepto establece. ${ }^{22}$ Asimismo, determina que "cuando resulte necesario para asegurar la defensa del orden jurídico y restablecer la confianza en la vigencia de la norma infringida por el delito, el juez o tribunal podrá acordar la ejecución de una parte de la pena que no podrá ser superior a dos tercios de su extensión, y sí la sustitución del resto por la expulsión del penado del territorio español". Se introduce la proporcionalidad como correctivo a la sustitución de la pena de prisión por la expulsión y se amplía la prohibición de sustitución al delito de trata de seres humanos del artículo 177 bis del Código Penal. ${ }^{23}$

\section{REQUISITOS PROCESALES DE VALIDEZ PARA IMPONER LA EXPULSIÓN PENAL}

\section{Oportunidad para solicitar la expulsión del condenado}

La pena sustitutiva de expulsión del territorio nacional solo puede ser solicitada y aplicada en audiencia judicial, no por despacho, previo debate entre los intervinientes interesados: el fiscal adjunto del Ministerio Público, el defensor y el acusado.

La ley exige la comparecencia de los intervinientes y de la autoridad competente ante el juez de garantía, en un procedimiento abreviado,

\footnotetext{
21 RompaO (2016) p. 2.

22 CANO (2015) p. 365.

23 Ídem., p. 366.
} 
GUTIÉRREZ MOYA, CARLOS: LA EXPULSIÓN COMO PENA CONTRA UN INMIGRANTE: ¿ES UN CASTIGO O UN PREMIO PARA EL CONDENADO EXTRANJERO SIN RESIDENCIA LEGAL?

establecido en los artículos 406 a 415 del Código Procesal Penal ${ }^{24}$, o en un procedimiento simplificado, regulado en los artículos 388 a 399 del Código Procesal Penal. Asimismo, ante un Tribunal de Juicio Oral en lo Penal Ilamado a decidir la controversia jurídica, en la audiencia de determinación de pena prevista en el artículo 343 del Código Procesal Penal.

Se exige además, por la ley, la presencia del abogado experto del Departamento de Extranjería y Migración del Ministerio del Interior y Seguridad Pública, en la audiencia de debate sobre la petición de expulsión penal.

A pesar de estar ejecutoriada la sentencia definitiva condenatoria que impone una pena privativa de libertad al acusado, el juez de garantía competente tiene la potestad para conocer la pretensión de la defensa tendente a que se sustituya la pena privativa de libertad por la expulsión del condenado extranjero del territorio nacional. El artículo 14 f) del Código Orgánico de Tribunales, señala la atribución del juez de garantía para: "Hacer ejecutar las condenas criminales y las medidas de seguridad, y resolver las solicitudes y reclamos relativos a dicha ejecución, de conformidad a la ley procesal penal". Se ha decidido por nuestro máximo tribunal que, aun dictado el fallo condenatorio por el Tribunal de Juicio Oral en lo Penal de Arica, la negativa del juez de garantía de no haber citado a la audiencia que señala el artículo 34 de la Ley $n^{\circ} 18.216$ modificada por la Ley $n^{\circ} 20.603$ de 2012, no se ajusta a lo prescrito por la ley, amenazando la libertad personal del amparado como consecuencia de la infracción de las normas mencionadas. ${ }^{25}$

\section{El acusado debe ser extranjero y además no tener residencia legal en Chile}

La expulsión penal afecta la libertad de entrada a Chile y de salida hacia el exterior de los extranjeros sin residencia legal en Chile. Son extranjeros todos quienes no son chilenos por ius soli, por ius sanguinis, por haber obtenido carta de nacionalización o en virtud de ley especial que otorga nacionalidad chilena por gracia, según el artículo 10 de la Constitución Política de la República. No es suficiente que el condenado sea extranjero, porque es necesario, además, que no tenga la calidad de residente según la ley en absoluto, o bien, que fuere residente pero en contravención a la ley chilena. El extranjero debe haber inmigrado clandestinamente evadiendo el control migratorio policial (entrada ilegal) o debe haber caducado la autorización

\footnotetext{
24 CeRDA (2004) pp. 54 y ss.

25 Corte Suprema, A favor de Y.M.Z. (2015, rol n 8726-2015).
} 
administrativa para permanecer en el país en virtud de una visa temporal (permanencia en forma irregular). Los "extranjeros turistas" son meros transeúntes, están de paso en el territorio chileno, carecen de residencia en Chile según el párrafo $6^{\circ}$ del Decreto Ley n 1.094 del 19 de julio de 1975, que establece normas sobre extranjeros en Chile. Por lo tanto, el turista también está comprendido en la expresión "un extranjero que no residiere legalmente en el país". ${ }^{26}$ Los extranjeros que gozan de una residencia temporaria, que es esencialmente provisoria y con miras a un interés concreto, tienen derecho a presentar una solicitud de permanencia definitiva en Chile, ante el Departamento de Extranjería y Migración del Ministerio del Interior y Seguridad Pública. Para estos efectos, deben Ilenar un formulario, acompañando a su petición todos los documentos requeridos por la autoridad, antes del vencimiento de su residencia provisoria. Una vez que está lista la última etapa de tramitación, la resolución respectiva es notificada al interesado mediante una carta certificada dirigida a su domicilio en Chile. Si la solicitud es aceptada, el extranjero obtiene la permanencia definitiva. En el evento de ser desestimada su petición, debe abandonar el país por no estar autorizado a permanecer en él. En todo caso, la administración está obligada a aportar al expediente todo el material probatorio necesario para acreditar que su decisión viene apoyada de una realidad fáctica que garantice legalidad y oportunidad de la misma, así como la congruencia y fines que la justifican. ${ }^{27}$

Corresponde al abogado del Ministerio del Interior y Seguridad Pública exponer durante la audiencia de imposición de pena sustitutiva que el acusado extranjero es un "indocumentado", un "sin papeles", porque ingresó de manera irregular al país, o que ha vencido su visa temporaria de turista o para fines de trabajo, de estudiante, u otra autorizada por la autoridad administrativa. O puede comunicar que si bien el condenado extranjero tenía visa de residencia temporaria, ha caducado su facultad para solicitar oportunamente la permanencia definitiva.

\section{Canje penal del acusado}

Además, debe estar adjunto en el Sistema de Apoyo a la Gestión Judicial ( «SIAG)») del Juzgado de Garantía, o en su caso, del Tribunal de Juicio Oral en lo Penal, el documento digitalizado de canje penal del acusado extranjero, que acredite su identificación completa, con nombres y apellidos correctos y su número de cédula de identidad chileno. También debe haber sido abierta la carpeta de extracto de filiación y antecedentes del acusado, que

\footnotetext{
26 Defensoría Penal Pública (2014) p. 151.

27 Dellacasa y Hurtado (2015) p.113.
} 
GUTIÉRREZ MOYA, CARLOS: LA EXPULSIÓN COMO PENA CONTRA UN INMIGRANTE: ¿ES UN CASTIGO O UN PREMIO PARA EL CONDENADO EXTRANJERO SIN RESIDENCIA LEGAL?

Ileva el Sub-departamento de Filiación Penal del Servicio de Registro Civil e Identificación, previa toma de huellas dactilares del afectado, Ilamado "canje penal de huellas".

\section{La expulsión penal es facultativa}

La imposición de la pena de expulsión es facultativa, porque no obliga al juez a decretarla, ya que la ley señala "podrá". La ventaja de que la expulsión penal no sea imperativa, permite al juez de garantía o al Tribunal Oral en lo penal decidir la conveniencia de aplicarla con buen criterio, a la luz de los hechos y circunstancias del caso concreto que deben resolver. Si ella se observa inadecuada en el caso concreto, por existir una situación de arraigo social en el país o proyecto migratorio vigente, el tribunal deberá preferir otra pena sustitutiva, según corresponda, a la pena originalmente impuesta. ${ }^{28}$

La ley no señaló la inexistencia de otros procesos penales pendientes en Chile como requisito para aplicar la pena sustitutiva de expulsión del territorio de la República. Podría acaecer que el condenado a esta pena sustitutiva debiera forzosamente salir del territorio de la República, sin haber sido juzgado por un segundo delito -u otros delitos- ante otro Juzgado de Garantía o Tribunal de Juicio Oral en lo Penal. Como la ley omite solucionar situaciones en que un mismo acusado extranjero tiene dos o más procesos pendientes ante tribunales diferentes, aplicar la pena sustitutiva de expulsión en el primer proceso penal frustraría el juzgamiento por el delito en la segunda causa criminal.

En casos más extremos, decretar la expulsión penal del condenado extranjero a su país de origen, que tuviere la calidad de refugiado, es una contravención al principio de no devolución reconocido en el artículo 33 de la Convención de Ginebra de 1951 sobre el Estatuto de los Refugiados, del Alto Comisionado para las Naciones Unidas (Non-refoulment principle). Esta obligación internacional de no devolución del refugiado, definida en su artículo $1^{\circ}$, debe ser aplicada cuando como resultado de los eventos que ocurren en el país de origen (guerra externa, guerra civil) no desea regresar a él debido a que su vida o su libertad pudiere ser amenazada, o se encontrare en peligro bien fundado de ser perseguido en razón de su raza, religión, ser miembro de una clase social u opinión política. La garantía del principio de no devolución también es asegurada en el artículo 22.8 de la Convención Americana sobre Derechos Humanos de 1969: "En ningún caso el extranjero puede ser expulsado o devuelto a otro país, sea o no de origen, donde su derecho a la

28 Defensoría Penal Pública (2014) p. 152. 
vida o a la libertad personal está en riesgo de violación a causa de raza, nacionalidad, religión, condición social o de sus opiniones políticas".

De acuerdo con las normas de Derecho Internacional Público, los tratados internacionales son vinculantes respecto del Estado parte desde que lo ha ratificado, de acuerdo con el procedimiento constitucional regulado en su derecho interno. En consecuencia, el Estado chileno tiene la obligación de no poner en peligro al extranjero condenado con ocasión de su penalización, es decir, debe castigar las conductas ilícitas con penas que no sean tan graves como para afectar su vida o su libertad personal.

La Convención de Viena sobre el Derecho de los Tratados de 1969 establece una regla importante en el sentido que un Estado parte no podrá invocar las disposiciones de su derecho interno como justificación del incumplimiento de un tratado. El Estado parte no puede alegar que como el ordenamiento jurídico nacional contiene un precepto constitucional, legal o reglamentario, que es diferente o contrario al artículo del tratado internacional, no sería válido incumplir su obligación señalada en el tratado internacional porque contraviene su derecho interno. La regla del artículo 27 de la Convención de Viena sobre el Derecho de los Tratados es clara. El Estado parte no puede invocar su derecho interno para incumplir sus obligaciones que emanan del tratado internacional. De lo contrario, cualquier país podría excusarse de incumplir un tratado internacional a pretexto de que su derecho nacional tiene disposiciones contrarias, diferentes o que se oponen a los preceptos del tratado internacional. Hay ciertas reglas de excusas o justificaciones respecto del incumplimiento de un tratado internacional, que son muy precisas, aplicables para casos graves, por ejemplo error, dolo, coacción del ministro plenipotenciario, etc., causas de caso fortuito o fuerza mayor. Si el Estado parte invoca su derecho interno para incumplir sus obligaciones que emanan del tratado internacional, podrá incurrir en responsabilidad internacional, porque no es válido dejar de aplicar ni suspender alguna de sus disposiciones.

\section{Oportunidad para imponer la expulsión del condenado}

La pena sustitutiva de expulsión del condenado del territorio de la República de Chile debe ser impuesta por el juez de garantía o el Tribunal de Juicio Oral en lo Penal, que debe resolver el asunto: "por el tribunal que las imponga" señala el Artículo $1^{\circ}$ inciso primero de la Ley n 18.216 modificada por la Ley $\mathrm{n}^{\circ} 20.603$ de 2012. La forma de redacción debe ser imperativa en la parte resolutiva de la sentencia definitiva que debe dictar, después de condenar al acusado a la pena privativa de libertad originaria. Por ejemplo, la sentencia definitiva declara que se condena al acusado M. A. B. S. a la pena privativa de libertad de 520 días de presidio menor en su grado mínimo. 
GUTIÉRREZ MOYA, CARLOS: LA EXPULSIÓN COMO PENA CONTRA UN INMIGRANTE: ¿ES UN CASTIGO O UN PREMIO PARA EL CONDENADO EXTRANJERO SIN RESIDENCIA LEGAL?

Más adelante, el fallo condenatorio ordena imponer la pena sustitutiva de expulsión penal, cuya lectura corresponde al juez de garantía o al presidente del Tribunal de Juicio Oral en lo Penal, que ha dictado la sentencia definitiva condenatoria:

"...III.- Que a petición de la Defensa, reuniendo el sentenciado M. A. B. S. al momento de la comisión del hecho punible, todos y cada uno de los requisitos previstos en el artículo 34 de la Ley $N^{\circ} 18.216$ reformado por la Ley $n^{\circ} 20.603$ que modifica la Ley $n^{\circ} 18.216$, y habida cuenta que ha sido citado en forma legal y oído don A. V., abogado del Departamento de Extranjería y Migración del Ministerio del Interior y Seguridad Pública; ha lugar a la petición del abogado defensor privado don L. R. Y. y de la fiscal del Ministerio Público doña M. B. M., se sustituye la pena privativa de libertad de quinientos veinte días de presidio menor en su grado mínimo impuesta al ciudadano peruano M. A. B. S., quien no tiene residencia legal en la República de Chile, y se impone al condenado M. A. B. S. la pena sustitutiva de expulsión del condenado M. A. B. S. del territorio de la República de Chile" ${ }^{29}$

\section{Apercibimiento para el caso de quebrantamiento}

Expulsión penal no es únicamente devolución forzada al país de origen. Es expulsión penal más prohibición de regresar a Chile. El juez o el Tribunal de Juicio Oral en lo Penal debe advertir de manera verbal y directa al condenado las consecuencias desfavorables del quebrantamiento de la expulsión penal. El condenado extranjero a quien le es aplicada esta pena sustitutiva de expulsión no podrá regresar al territorio nacional en un plazo de 10 años, contado desde la fecha de la sustitución de la pena. En caso que el condenado regresare al territorio nacional dentro del plazo de 10 años, contado desde la fecha de la sustitución de la pena, se revocará la pena de expulsión, debiendo cumplir el saldo de la pena privativa de libertad originalmente impuesta.

Con la dictación del veredicto y de la sentencia definitiva condenatoria, el sentenciado deberá permanecer bajo internación en el Centro de Detención Preventiva de Gendarmería de Chile que determine el juez o el Tribunal de Juicio Oral en lo Penal, hasta que se concrete su expulsión del territorio nacional. La ley no estableció un plazo perentorio para materializar la expulsión penal. Con todo, nuestra Excelentísima Corte Suprema ha decidido, conociendo de un recurso de amparo por vía de apelación, que

295 Juzgado de Garantía de Santiago, Ministerio Público contra M.A.B.S. (2016, RIT n 907-2015) parte resolutiva. 
"para que la norma sea eficaz, la sustitución debe materializarse en un término razonable, de modo que no se torne en una situación más gravosa que la pena privativa de libertad que viene a remplazar, lo que es coherente con el principio de celeridad contenido en la Ley $n^{\circ}$ 19.880, que establece las Bases de los Procedimientos Administrativos que rigen los Actos de los Órganos de la Administración del Estado (...)". ${ }^{30}$

\section{Reconocimiento de abonos}

La sentencia definitiva condenatoria debe contener expresamente la mención de todos los abonos que favorecen al sentenciado, según lo ordenado por el artículo 348 del Código Procesal Penal. Vale decir, debe fijar con precisión todo el tiempo que el condenado estuvo detenido, sujeto a prisión preventiva o bajo privación total de libertad en su domicilio, con ocasión de la causa criminal en que fue declarado culpable. Este tiempo de privación de libertad que sufrió el sentenciado debe ser descontado de la pena privativa de libertad por el juez o tribunal que lo ha juzgado. Mientras tanto, el sentenciado debe permanecer bajo internación en un Centro de Detención Preventiva de Gendarmería de Chile, hasta que se concrete su expulsión del territorio nacional. En todo caso, la internación no podrá jamás ser superior al tiempo que corresponda al cumplimiento íntegro de la pena privativa de libertad impuesta.

\section{Recurso procesal contra a la expulsión}

Según lo dispuesto en el artículo 37 de la Ley $\mathrm{n}^{\circ} 18.216$ modificada por la Ley $n^{\circ} 20.603$ de 2012, la resolución que concede, deniega, revoca, sustituye, reemplaza, reduce, intensifica o termina anticipadamente alguna de las penas sustitutivas, incluyendo la pena sustitutiva de expulsión penal, puede ser impugnada vía recurso de apelación, según las reglas generales, por el interviniente que ha resultado agraviado.

El artículo 362 del Código Procesal Penal preceptúa que la apelación debe concederse en el solo efecto devolutivo, vale decir, la interposición del recurso de apelación no suspende el cumplimiento de la resolución impugnada, debiendo continuar la etapa de ejecución de la sentencia definitiva, de manera regular. La excepción es decretar una orden de no innovar, por la Corte de Apelaciones, a petición del apelante.

30 Corte Suprema, sentencia rol no 70-2014, citado en Defensoría Penal Pública (2014) p. 154. 
GUTIÉRREZ MOYA, CARLOS: LA EXPULSIÓN COMO PENA CONTRA UN INMIGRANTE: ¿ES UN CASTIGO O UN PREMIO PARA EL CONDENADO EXTRANJERO SIN RESIDENCIA LEGAL?

El inciso segundo del artículo 37 de la Ley $\mathrm{n}^{\circ} 18.216$ modificada por la Ley $\mathrm{n}^{\circ} 20.603$ de 2012, regula el plazo de interposición del recurso de apelación, y la hipótesis de recurrir únicamente contra la decisión que se pronuncia sobre la imposición o rechazo de la pena sustitutiva, o bien impugnar toda la sentencia definitiva: "Cuando la decisión que conceda o deniegue una pena sustitutiva esté contenida formalmente en la sentencia definitiva, el recurso de apelación contra dicha decisión deberá interponerse dentro de cinco días siguientes a su notificación o, si se impugnare además la sentencia definitiva por la vía del recurso de nulidad, se interpondrá conjuntamente con éste, con carácter de subsidiario y para el caso en que el fallo del o de los recursos de nulidad no altere la decisión del tribunal a quo relativa a la concesión o denegación de la pena sustitutiva".

\section{EJECUCIÓN DE LA EXPULSIÓN PENAL}

En la etapa aplicativa, judicial o de imposición de la pena, el fin preventivo general se concretaría en el hecho de que la imposición de la pena por el juez es la confirmación de la seriedad de la amenaza abstracta expresada en la ley, porque prueba que la amenaza penal iba en serio. ${ }^{31} \mathrm{El}$ momento represivo de la sanción tenderá al fin secundario -si bien imprescindible- de ratificar la pretensión de respeto de la norma, reafirmando simbólicamente la corrección de la norma misma, y al fin de confirmar la seriedad de la amenaza. ${ }^{32}$ La implementación de la expulsión penal es ordenada en la parte resolutiva de la sentencia definitiva, otorgando al Departamento de Extranjería y Migración del Ministerio del Interior y Seguridad Pública un plazo razonable y prudente, para los efectos de practicar de manera adecuada la implementación y la ejecución de la pena sustitutiva de expulsión ordenada, ordenando la remisión del oficio correspondiente.

La aplicación de la pena sustitutiva no es instantánea, pues es necesario un tiempo breve, para obtener los fondos para comprar billetes de pasajes aéreos y otorgar viáticos a los funcionarios de Policía de Investigaciones de Chile que escoltarán al condenado expulsado. En la práctica, el abogado experto solicita un plazo de 60 días, estándar, durante el cual se realizarán todas las gestiones conducentes a materializar la expulsión penal.

Antes de que venza este plazo, los agentes de custodia de la Policía de Investigaciones de Chile se encargan de ir a buscar y presentarse a retirar al

\footnotetext{
$31 \quad$ SANZ (2008) p. 14.

32 AlCÁCER (2001) p. 258.
} 
extranjero que ha sido condenado por sentencia firme a expulsión penal, en el centro de detención preventiva en que se encuentra bajo internación.

El Inspector de Policía Internacional, el Alcaide y el Jefe de la sección de Estadística firman un "Acta de entrega para expulsión", en el que consta que se "hace entrega" a la Jefatura Nacional de Extranjería y Policía Internacional del condenado extranjero, perfectamente individualizado con sus datos personales. Se acostumbra añadir que "el interno" se encuentra en buenas condiciones de salud y apto para el traslado. Finaliza con la mención de inexistencia de reclamos del recluso contra la Administración Penitenciaria.

En seguida, el condenado extranjero es trasladado por los funcionarios de Policía de Investigaciones de Chile en un vehículo policial, rumbo al aeropuerto Comodoro Arturo Merino Benítez de Santiago de Chile, con destino al aeropuerto de la ciudad del país de origen del extranjero condenado, o de la capital del Estado del que es nacional. Los agentes de custodia de la Policía de Investigaciones de Chile deben abordar un avión comercial y viajar junto al extranjero condenado durante el traslado, hasta arribar al aeropuerto del lugar de destino del vuelo. El propósito de acompañar al extranjero condenado durante su travesía es obtener la certeza de la salida forzosa del extranjero condenado de nuestro país, y además no poner en riesgo la seguridad aérea de los pasajeros y la tripulación del avión comercial en que viaja.

\section{LOS FINES DE LA PENA DE EXPULSIÓN}

Analicemos si es plausible justificar la pena sustitutiva de expulsión del condenado extranjero no residente en Chile en conformidad a la ley, a la luz de las diversas teorías de la pena que han sido formuladas a lo largo de la historia.

\section{Teorías absolutas de la pena}

Las teorías absolutas son aquellas que desvinculan la pena de su autor. Según la justificación retributiva, en primer lugar, la sanción penal es "el mal merecido por la infracción culpable". ${ }^{33}$ Immanuel Kant sostenía lo siguiente: "El asesino, entonces debe morir; aquí no hay ningún sustituto para satisfacer la justicia" ${ }^{34}$ y que debería ejecutarse hasta el último asesino que se hallase en prisión, únicamente "para que todos comprendieran el valor

\footnotetext{
33 Welzel (1993) p. 286

34 KANt, Metafísica de las Costumbres, p. 333 citado por MIR (2011).
} 
GUTIÉRREZ MOYA, CARLOS: LA EXPULSIÓN COMO PENA CONTRA UN INMIGRANTE: ¿ES UN CASTIGO O UN PREMIO PARA EL CONDENADO EXTRANJERO SIN RESIDENCIA LEGAL?

de sus actos". ${ }^{35}$ De acuerdo con esta teoría "la función de la pena consiste en la realización de la justicia". ${ }^{36}$ El "castigo justo" es "un acto de justicia compensatoria o venganza". ${ }^{37}$ Según una variante de la teoría absoluta, los seguidores de la teoría de la expiación creen que la pena es necesaria para la fuerza de formación moral del delincuente, que se adquiere mediante la aplicación judicial efectiva de las penas de prisión, presidio o reclusión. Esta afirmación es especialmente correcta cuando no se imponen penas sustitutivas a los condenados.

Las teorías absolutas, y en particular la concepción retributiva, tienen en común que "la pena ha de imponerse por el delito cometido aunque resulte innecesaria para el bien de la sociedad". ${ }^{38}$

En segundo lugar, la pena es la retribución justa del mal causado por el condenado. La gravedad de la pena debe ser medida en base a la culpabilidad del autor, cómplice o encubridor. La justicia de la pena radica en que debe ser equivalente, o al menos proporcionada, a la gravedad del delito cometido.

De este modo, el culpable de cometer un delito que afecta a uno de los bienes jurídicos más preciados por el ordenamiento jurídico, debe merecer una pena fuerte. "El sentimiento de confianza en el derecho por parte de los hombres, se corrompe, así se dice, por una inadecuada absolución o un castigo suave" ${ }^{39}$ : "A mayor ofensa, más grave el castigo".

A la inversa. Si la pena debe "corresponder" a la magnitud de la culpabilidad, está prohibido en todo caso dar un escarmiento mediante una penalización drástica en casos de culpabilidad leve ${ }^{40}$ : "A menor ofensa, más leve el castigo".

El condenado extranjero sin residencia legal en Chile puede cometer un delito grave, cuya pena no exceda de cinco años de presidio menor en su grado máximo y, sin embargo, no sufrirá pena privativa de libertad efectiva. Tampoco se impondría en su contra la remisión condicional, ni la reclusión parcial nocturna, como tampoco la libertad vigilada simple o intensiva. Únicamente merecería la pena sustitutiva de expulsión penal, que de no resultar impuesta

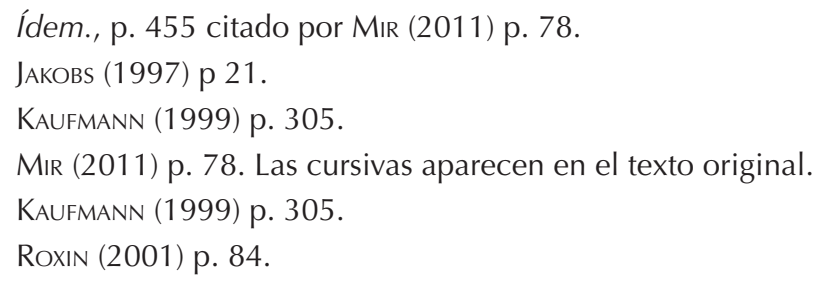


en su contra, se aplicaría la deportación administrativa señalada en el Decreto Ley $n^{\circ} 1.094$ de 1975, Ley de Extranjería. Evidentemente no se restablece el equilibrio natural, porque el castigo impuesto es menor a la ofensa causada.

Además, el crimen organizado puede ser favorecido con la expulsión penal. ${ }^{41}$ Esto se debe a que la pena de cinco años de presidio o reclusión es considerada "en concreto", pues es la pena impuesta por el juez de garantía o por el Tribunal de Juicio Oral en lo Penal. No se refiere a la pena "en abstracto" que señala la ley penal. Hay crímenes graves que no se excluyeron expresamente en el artículo $1^{\circ}$ de la Ley $n^{\circ} 18.216$ modificada por la Ley $n^{\circ}$ 20.603. Luego, en virtud de la concurrencia de circunstancias atenuantes de responsabilidad penal, pueden quedar en definitiva en cinco años de presidio o reclusión menor en su grado máximo, o incluso menos. Pensemos en el tráfico de migrantes, la trata de personas para fines de explotación sexual, laboral o extracción de órganos humanos, el lavado de activos, la asociación ilícita, conductas terroristas, etc.

\section{Teorías relativas de la pena}

Para las teorías relativas, la pena es tan solo una medida práctica para impedir la comisión de delitos, sin importar la retribución, o la justicia material, ni la expiación del delincuente.

\section{A) TeORÍAs PREVENTIVAS GENERALES}

a) La prevención general positiva persigue reafirmar el respeto a los bienes jurídicos protegidos penalmente, salvaguardando la vigencia del ordenamiento jurídico. La comisión de delitos debe ser castigada, para demostrar a la comunidad que quien atenta contra el sistema jurídico no quedará impune, pues "misión de la pena es el mantenimiento de la norma como modelo de orientación para los contactos sociales. Contenido de la pena es una réplica, que tiene lugar a costa del infractor, frente al cuestionamiento de la norma" ${ }^{\prime 2}$ : "A mayor pena, más valioso el bien jurídico protegido por la ley penal".

Si se interpretara que la blandura de la expulsión penal significa que nuestro poder legislativo (Congreso Nacional) ha subestimado los valores de la comunidad, entonces el establecimiento en la ley y la aplicación judicial de esta pena sustitutiva. Porque la sensación de impunidad de los autores de

${ }_{41}$ Véase con más detalle Albrecht (2001) y Favarel-Garrigues (2002).
42 Jakobs (1997) p. 14. 
GUTIÉRREZ MOYA, CARLOS: LA EXPULSIÓN COMO PENA CONTRA UN INMIGRANTE: ¿ES UN CASTIGO O UN PREMIO PARA EL CONDENADO EXTRANJERO SIN RESIDENCIA LEGAL?

delitos generará con toda seguridad en la gente común una gran desazón y desconfianza en el sistema judicial.

b) Las teorías preventivas generales negativas "ven el principal efecto, y con él el principal fin de la pena, en la inhibición sicológica del delito sobre la generalidad (intimidación) [...] mediante ejecución ejemplarizadora de la pena [...] (o) a través de graves conminaciones de penas". ${ }^{43}$ Esta prevención tiende a evitar ataques a bienes jurídicos en la medida de su gravedad y de su peligrosidad, los dos baremos básicos de la selección de la incriminación penal y de la graduación de la pena. ${ }^{44} \mathrm{~A}$ este fin de la pena se le Ilama prevención general negativa, porque amenaza -a todos y cada uno de los destinatarios de la norma jurídica- con miras a producir un efecto disuasivo, formulando una advertencia que motiva a abstenerse de cometer delitos. Da por sentado que mientras más alta sea la pena establecida por la ley, mayor será el incentivo para no cometer el hecho punible castigado con dicha pena.

Por ejemplo, la pena mínima de tres años y un día de presidio menor en su grado máximo, de cárcel, para los condenados en calidad de autores del delito de posesión, tenencia o porte ilegal de arma de fuego, o por delito de porte de arma de fuego prohibida, y otros afines, a contar de la entrada en vigencia de la Ley $\mathrm{n}^{\circ} 20.813$ de 2015, el nuevo artículo 17 B de la Ley $\mathrm{n}^{\circ}$ 17.798 de Control de Armas prohíbe bajar del grado menor de la pena compuesta: "[...] el tribunal no tomará en consideración lo dispuesto en los artículos 65 a 69 del Código Penal y, en su lugar, determinará su cuantía dentro de los límites de cada pena señalada por la ley al delito, en atención al número y entidad de circunstancias atenuantes y agravantes, y a la mayor o menor extensión del mal producido por el delito". ${ }^{45}$ Asimismo, el artículo $1^{\circ}$ inciso segundo de la Ley $\mathrm{n}^{\circ} 18.216$ no permite al juez o tribunal imponer ningún tipo de pena sustitutiva: "No procederá la facultad establecida en el inciso precedente [...] tratándose de los autores de los delitos consumados previstos en [...] los artículos $8^{\circ}, 9^{\circ}, 10,13,14$ y $14 \mathrm{D}$ de la ley $n^{\circ}$ 17.798; o de los delitos o cuasidelitos que se cometan empleando alguna de las armas o elementos mencionados en las letras a), b) c), d) y e) del artículo $2^{\circ}$ y en el artículo $3^{\circ}$ de la citada ley $n^{\circ} 17.798$, salvo en los casos en que la determinación de pena se hubiere considerado la circunstancia primera establecida en el artículo 11 del mismo Código", que se cometan. Esta modificación ha tenido el propósito de endurecer excesivamente las penas de la Ley $\mathrm{n}^{\circ} 17.798$ de Control de Armas, prescindiendo de criterios de retribución y proporcionalidad, con

43 Así lo sostiene la teoría de la coacción psicológica de FeUERBACH, cfr. Welzel (1993) p. 285.

$44 \quad$ MIR (2011) p. 98.

45 BuDINICH (2016) p. 277. 
miras a desarmar a los delincuentes habituales, en primer lugar, y para evitar la venganza privada o justicia de mano propia de los ciudadanos comunes, en segundo lugar. En un sentido más amplio, la prevención general es la verificación del derecho como orden ético (dimensión positiva), y solo en forma secundaria es intimidación (dimensión negativa): "A mayor pena, más baja la tasa de delitos".

Lo más probable es que el condenado extranjero no conozca la gravedad de las penas que arriesga si cometiere delitos en Chile. Pero si las conociera, sabría que puede cometer todos los simples delitos que quisiera, siempre que las penas en conjunto no excedan de cinco años de presidio menor en su grado máximo, o perpetrar crímenes que en virtud de concurrir dos o más atenuantes pueden disminuir el marco penal aplicable en el caso concreto a no más de cinco años, y sin embargo, es consciente de que no sufrirá una pena a ser cumplida en la cárcel. Únicamente deberá soportar la expulsión penal, que de no mediar, se aplicaría la deportación administrativa señalada en el Decreto Ley n 1.094 de 1975, Ley de Extranjería. Evidentemente no se restablece el equilibrio natural, porque el castigo impuesto con la expulsión penal es mucho menor a la ofensa causada.

Las teorías preventivas generales han sido criticadas, porque justifican establecer penas desproporcionadas o injustas, en relación con la entidad del hecho tipificado como delito. Además, está comprobado que las leyes penales draconianas no sirven para motivar ni constreñir a sus destinatarios.

\section{B) TEORÍAs PREVENTIVAS ESPECIALES}

Las teorías preventivas especiales pretenden conseguir la prevención de los delitos mediante una actuación sobre el recluso. Toman como medida para la pena la peligrosidad del autor (en especial su reincidencia), para lo cual el hecho tiene solo el valor de síntoma. ${ }^{46}$ La justificación de la pena es para efectos de que el condenado no vuelva a delinquir, busca la rehabilitación del autor, su reinserción en la sociedad, transformarlo en un hombre nuevo que no será más un peligro para el Estado, ni para las demás personas. Si no hay peligro de que el condenado vuelva a cometer otro delito, no debe aplicarse ninguna pena privativa de libertad efectiva. Las teorías preventivas especiales son criticadas en razón a que conducen a resultados injustos e incluso insólitos: "Si hay un pequeño peligro de repetición, se concluye también que para delitos graves habrá que aplicar una pena ínfima (Denkzettel)"47: "A

\footnotetext{
$46 \quad$ Welzel (1993) p. 286.

47 Ibídem.
} 
GUTIÉRREZ MOYA, CARLOS: LA EXPULSIÓN COMO PENA CONTRA UN INMIGRANTE: ¿ES UN CASTIGO O UN PREMIO PARA EL CONDENADO EXTRANJERO SIN RESIDENCIA LEGAL?

menor peligrosidad social, menor pena". "Como a la inversa, en el caso de gran peligro de repetición se llega a penas graves por hechos insignificantes ( $p$. ej., en contra del tramposo habitual)"48: "A mayor peligrosidad social, mayor pena".

La expulsión penal es aplicable a todo tipo de simple delito y a la mayoría de los crímenes, salvo los excluidos, que por efectos de la concurrencia de circunstancias atenuantes de responsabilidad penal correspondiere una pena de presidio o reclusión menor en su grado máximo que no supere de cinco años.

La prevención especial negativa pretende neutralizar al sujeto peligroso, inocuizar al enemigo de la comunidad, utilizando técnicas de exclusión social, prescindiendo de medidas rehabilitadoras. Desde la perspectiva del tratamiento penal de los migrantes, "nuestro actual modelo político-criminal presenta altos grados de hibridación entre dos extremos representados por la garantía de la inclusión (resocialización, rehabilitación) y por el mantenimiento en situaciones de exclusión (inocuización, neutralización)" ${ }^{49}$

La legitimidad de la aplicación de la pena sustitutiva de expulsión del territorio nacional dependerá de su concordancia hacia alguno de los fines de la pena. Esto será así, porque "la expulsión puede ser una alternativa al encierro carcelario, siempre y cuando se oriente a la garantía de los derechos humanos y a no perseguir finalidades defensistas o de orden público del Estado".$^{50}$

Ladrones, receptadores, clonadores de tarjetas de crédito y débito, traficantes de migrantes, proxenetas (intermediarios entre prostitutas y clientes ${ }^{51}$ ), traficantes de drogas, microtraficantes conocidos con el apodo de "correos humanos" o "mulas" y blanqueadores de capitales ${ }^{52}$, entre otros, pueden resultar beneficiados con la pena sustitutiva de expulsión del territorio de la República. Es muy difícil encajar la expulsión penal en alguna de las definiciones sobre los fines de la sanción penal. La más parecida es la prevención especial negativa, que pretende únicamente la neutralización del condenado, sin resocialización. ¿Cuál es la justificación de esta pena? Surge el concepto de nuevo cuño "economía política de la pena". Es utilitarismo puro y duro,

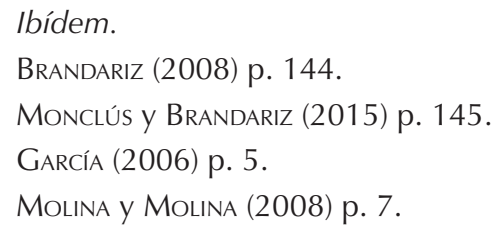


con el propósito de abaratar costos al Fisco de Chile. Es la necesidad de ahorrar todos los gastos en que incurriría el Estado, por el mantenimiento de presos extranjeros en establecimientos penitenciarios. La lógica que parece asumir el estatuto jurídico para el migrante es la de la exclusión potencial ${ }^{53}$, en las consecuencias jurídicas que en la última etapa se reservan para articular el régimen sancionador-administrativo y penal- de los migrantes irregulares (expulsión, internamiento, prisión sin posibilidad de suspensión de la ejecución), la segregación parece emerger como finalidad primordial de la sanción. ${ }^{54}$

A modo ilustrativo, citaremos algunas críticas que han sido formuladas contra la pena de expulsión de extranjeros. Adela Asúa Batarrita ha negado que la expulsión del artículo 89 del Código Penal español sea una pena verdadera. Sostiene que es una medida administrativa sancionatoria trasplantada desde la política de control de la inmigración. ${ }^{55}$

Sebastián Salinero Echeverría ha concluido en su investigación especializada que la expulsión penal no busca la prevención especial positiva, porque no resocializa al condenado extranjero, ni en Chile ni en su país de origen. En consecuencia, la pena sustitutiva de expulsión no es más que "una clara renuncia al ius puniendi" 56 (potestad del Estado para establecer delitos y penas) y que "la administración penitenciaria o el buen funcionamiento de las cárceles chilenas no puede constituir un valor por sí solo que esté por sobre el deber del Estado de ejercer el poder social de castigo sobre el infractor de la ley penal". ${ }^{57}$

En Argentina la expulsión de migrantes irregulares condenados está regulada en el art. 64 de la Ley de Migraciones $n^{\circ} 25.871$. El inciso a) exige como requisito para la aplicación de la expulsión de los extranjeros irregulares: "una vez hayan cumplido la mitad de la condena", provocando la extinción de la pena. Mientras que en Chile la expulsión preceptuada en el artículo 34 de la Ley 18.216 es una pena que sustituye completamente a la pena privativa de libertad originalmente impuesta, en Argentina la expulsión prevista en el artículo 64 de la Ley de Migraciones n² 25.871 tiene efectos parciales, posibilitando la sustitución de la pena privativa de libertad mediante un egreso anticipado. En tal sentido, "en la práctica la expulsión funciona como un

\footnotetext{
53 Brandariz (2008) p. 237.

54 Pérez (2006) p. 173.

55 Asúa (2002) p. 63.

56 SAlinero (2011) p. 124.

57 Ibídem.
} 
GUTIÉRREZ MOYA, CARLOS: LA EXPULSIÓN COMO PENA CONTRA UN INMIGRANTE: ¿ES UN CASTIGO O UN PREMIO PARA EL CONDENADO EXTRANJERO SIN RESIDENCIA LEGAL?

sustitutivo del régimen penitenciario progresivo, como las salidas transitorias, semilibertad o libertad condicional" ${ }^{58}$ Este régimen híbrido de cumplimiento parcial de la pena privativa de libertad de manera real, más la posterior expulsión penal, tiene la ventaja de asegurar el cumplimiento efectivo de la pena de cárcel impuesta desde la mitad hacia adelante. Esta omisión del requisito de cumplir la mitad de la pena privativa de libertad es la prueba más patente de que la expulsión penal regulada en la Ley 18.216 tiene como finalidad principal el ahorrar gastos de recursos fiscales, eludiendo la carga de asumir los costos de mantener presos extranjeros en establecimientos penitenciarios.

\section{C) TEORÍA PREVENTIVA MIXTA O UNIFICADORA}

La teoría preventiva mixta o unificadora ha sido formulada por Claus Roxin. Tiene la virtud de combinar la función motivadora de la conminación penal de la prevención general, con la resocialización del condenado según la prevención especial positiva. De este modo, "coloca los puntos de vista preventivo-especiales y generales en un sistema cuidadosamente equilibrado, que solo en el ensamblaje de sus elementos ofrece fundamento teórico a la pena estatal". ${ }^{59} \mathrm{El}$ derecho penal está autorizado para corregir al delincuente, pero sin forzarlo, pues debe respetar su autonomía personal, su voluntad de cambiar, brindándole herramientas suficientes para que aprenda a respetar los bienes jurídicos protegidos por la ley penal. A su vez, los ciudadanos sienten seguridad y confían en el sistema penal, cuyas normas jurídico-penales y sanciones penales correspondientes desincentivan la comisión de futuros delitos, frenando el impulso criminógeno en la mayoría de los habitantes del Estado. La configuración legal de la pena de expulsión de extranjeros, tanto en España como en Argentina, ha considerado este modelo mixto o unificador, que en Chile no existe.

\section{V. ¡ES LA EXPULSIÓN PENAL CONFORME CON LA IGUALDAD ANTE LA LEY?}

\section{Condición de extranjero como categoría sospechosa de discriminación}

Las circunstancias fortuitas que escapan al control personal consciente, por ejemplo el lugar de nacimiento o un accidente que deja lisiado, ya que no dependen del mérito o la virtud, deben ser consideradas irrelevantes para distinguir entre unos y otros. En consecuencia, no autorizan a los poderes

\footnotetext{
58 Monclús y Brandariz (2015) p. 145.

$59 \operatorname{Roxin}(2001)$ p. 98.
} 
públicos dotados de potestades normativas a constituir tratos diferenciados donde no hay justificación razonable para hacerlo. La condición de extranjero no es considerada como un criterio sospechoso cuando se juzga la validez de clasificaciones normativas que excluyen a extranjeros y encomiendan solo a ciudadanos cargos electivos y no electivos importantes relacionados con el proceso de autogobierno democrático. ${ }^{60}$ En los demás casos, las diferencias de trato por la ley en razón a ser extranjero caen dentro de la categoría sospechosa de diferencia arbitraria. Se acusa el carácter discriminatorio de esta pena respecto de personas en situación irregular, pero con proyecto migratorio en el país. ${ }^{61}$ En consecuencia, las reglas especiales de tratamiento a los extranjeros deben ser examinadas con sumo cuidado, para descartar tan indeseable discriminación.

Partiendo del presupuesto según el cual el derecho a la igualdad ante la ley es consustancial a la dignidad humana, que el condenado carezca de residencia legal en Chile no debiera ser una razón suficiente para diferenciar entre un nacional y un extranjero, en lo que respecta a la aplicación de la ley penal en el territorio nacional.

\section{Reglas de trato igualitario y diferenciado}

Aristóteles afirmaba en su obra Ética a Nicómaco, Capítulo 6 del Libro V, que "si las personas son iguales, las cosas otorgadas a ellos también deberían ser iguales... Si las personas no son iguales, no deberían tener en partes iguales". ${ }^{62}$ Esta regla de trato simplificada en el aforismo "hay que tratar de manera igual a los iguales y de manera desigual a los desiguales", presenta problemas graves de ambigüedad e indeterminación. El lema jedem das seine, fijo en la reja de entrada al campo de concentración en Buchenwald, de la Alemania nacionalsocialista, ha demostrado ser peligroso cuando el gobierno distingue entre seres humanos e infrahumanos. La máxima de filosofía moral "dar a cada uno lo suyo" ha sido y puede continuar siendo utilizada como pretexto para establecer privilegios para unos o para excluir y reprimir a otros.

Las normas jurídicas deben ser interpretadas conforme a la Constitución Política de la República. Esta asegura a todas las personas "la igualdad ante la ley. En Chile no hay persona ni grupo privilegiado... Ni la ley ni autoridad alguna podrán establecer diferencias arbitrarias" (artículo 19 n 2). La estructura lógico-jurídica del derecho abstracto a la igualdad ante la

\footnotetext{
60 Didier (2012) p. 133. Cita la decisión Bernal v. Fainter, 467 U.S. 216 (1984).

61 Defensoría Penal Pública (2014) pp. 151 y 152.

62 Aristóteles (1943) pp. 159 y 160.
} 
GUTIÉRREZ MOYA, CARLOS: LA EXPULSIÓN COMO PENA CONTRA UN INMIGRANTE: ¿ES UN CASTIGO O UN PREMIO PARA EL CONDENADO EXTRANJERO SIN RESIDENCIA LEGAL?

ley (inciso primero del artículo $19 \mathrm{n}^{\circ} 2$ de la Constitución), o "derecho a la igualdad definitivamente abstracto", es formulada por Robert Alexy mediante dos reglas de conducta, en un orden preciso. En primer lugar, el derecho abstracto a la igualdad ante la ley contiene un mandato de tratamiento igual, el cual ordena que "si no hay ninguna razón suficiente para la permisión de un tratamiento desigual, entonces está ordenado un tratamiento igual". ${ }^{63} \mathrm{En}$ segundo lugar, prescribe el mandato de tratamiento desigual "si hay una razón suficiente para ordenar un tratamiento desigual, está ordenado un tratamiento desigual". ${ }^{64}$ En virtud del mandato de tratamiento igual, contenido en el derecho abstracto a la igualdad ante la ley, no hay argumentos ni se puede justificar razonablemente que el acusado extranjero sin residencia legal quede exento de la pena privativa de libertad que establece el Código Penal o una ley penal especial.

Desde este punto de vista del principio de igualdad formal y genérica, por regla general la expulsión penal es un tratamiento privilegiado inmerecido, que resulta más benigno que la imposición de penas privativas de libertad que sean reales o efectivas a los extranjeros residentes y a los nacionales. La potestad punitiva del Estado chileno -ius puniendi-se rige por el principio de territorialidad de la ley penal, esto es, la ley penal chilena debe ser aplicada de igual manera a todas las personas que hubieren cometido un delito dentro de los límites fronterizos de nuestro país.

La prisión preventiva jamás debe exceder la extensión de la pena privativa de libertad. Los fines de la prisión preventiva solo pueden ser fines de aseguramiento del procedimiento y de la ejecución, porque la legitimación de la prisión preventiva se deriva exclusivamente de tales intereses de aseguramiento. ${ }^{65}$ Sin embargo, en la práctica puede ocurrir que la expulsión penal resulte ser una pena más grave que la pena privativa de libertad. Si la pena privativa de libertad impuesta en la sentencia definitiva condenatoria fuere inferior al período de duración de la prisión preventiva, entonces la pena de expulsión resultaría un perjuicio injustificado para el condenado. Sería preferible declarar la culpabilidad y condenar al acusado a una pena privativa de libertad. Y a continuación, tener por cumplida la pena privativa de libertad para el condenado, con el mayor tiempo que ha permanecido sujeto a prisión preventiva, o a privación total de libertad en su hogar prevista en el artículo 155 a) del Código Procesal Penal.

\footnotetext{
$63 \quad$ Alexy (1997) p. 395.

64 Ídem., p. 397.

65 Hassemer (2003) p. 119.
} 


\section{EFECTOS DE LA EXPULSIÓN PENAL EN LA TUTELA JUDICIAL EFECTI- VA DE LA VÍCTIMA}

La aplicación de la pena sustitutiva de expulsión del territorio nacional a un condenado extranjero que no reside legalmente en Chile, prevista en el artículo 34 de la Ley $n^{\circ} 18.216$ modificada por la Ley $n^{\circ} 20.603$ de 2012, ha sido cuestionada porque lesionaría el derecho a la tutela judicial mediante la denegación de justicia a las víctimas de un delito.

La víctima en el proceso penal chileno tiene derecho a ejercer la acción civil, para obtener la reparación de los perjuicios que le ha causado el delito cometido por el acusado. El diseño estructural de las penas sustitutivas a la pena privativa de libertad, a partir de la Ley $n^{\circ} 20.603$, ha descartado la condición de reparar el daño causado por el delito cometido. Prueba de esto es que fue suprimida la condición para que el juez pudiera conceder la medida alternativa de remisión condicional de la pena. Estaba contenida en la derogada letra d) del artículo $4^{\circ}$ de la Ley n ${ }^{\circ}$ 18.216: "Satisfacción de la indemnización civil, costas y multas impuestas por la sentencia. No obstante el tribunal, en caso de impedimento justificado, podrá prescindir de esta exigencia, sin perjuicio de que se persigan estas obligaciones en conformidad a las reglas generales". En la actualidad, ninguna pena sustitutiva exige el requisito para su imposición del pago íntegro de la indemnización de perjuicios. El ofendido se puede introducir al procedimiento penal y participar en él, si se pretende la reposición del daño material y moral por el delito que constituye su objeto. ${ }^{66}$ El derecho a la tutela judicial efectiva comprende el derecho a la ejecución, definido como "el derecho a que sean ejecutadas las resoluciones que se dictan en favor de un litigante" ${ }^{67}$, vale decir, que se cumpla el resultado favorable obtenido con ocasión del proceso. Significa que el condenado debe sufrir la pena que ha sido impuesta en la sentencia definitiva y debe pagar la indemnización de los perjuicios causados al ofendido por el delito.

El plazo de 60 días, que el Departamento de Extranjería e Inmigración solicita para la materialización de la expulsión del condenado extranjero sin residencia legal, es demasiado breve para permitir a la víctima obtener la satisfacción de su derecho a la acción civil ejercitada en el proceso penal, en la mayoría de los casos. Esta dificultad temporal permite al condenado extranjero sin residencia legal en Chile evitar una condena civil, o de resultar condenado, evadir el pago de la indemnización de perjuicios otorgada por el juez a la víctima en el proceso penal.

\footnotetext{
$66 \quad$ MAYER (1997) p. 345.

$67 \quad$ NiEVA (2014) p. 159.
} 
GUTIÉRREZ MOYA, CARLOS: LA EXPULSIÓN COMO PENA CONTRA UN INMIGRANTE: ¿ES UN CASTIGO O UN PREMIO PARA EL CONDENADO EXTRANJERO SIN RESIDENCIA LEGAL?

\section{CONCLUSIONES}

1. Nuestra propuesta es la aplicación judicial restrictiva y prudente de la expulsión del condenado extranjero del territorio nacional. No recomendamos imponer esta pena sustitutiva cuando ésta implique la separación del condenado de su familia directa radicada en Chile, por no resultar criteriosa la destrucción de su proyecto migratorio. Tampoco cuando la expulsión penal pueda poner en riesgo su vida o libertad personal en calidad de asilado o refugiado.

2. Recomendamos respetar la dignidad humana y no anular la autonomía personal del condenado. Para lograr este objetivo, la expulsión penal sea solicitada por la defensa y jamás contra la voluntad del acusado, como condición sine qua non para su imposición. Los mejores intereses del autor del delito deben ser tomados en cuenta al momento de debatir y decidir su destino. No se vería bien que el fiscal adjunto del Ministerio Público pidiera o el juez de garantía impusiese la expulsión penal en perjuicio del condenado, con el propósito de deshacerse por un largo tiempo de una persona que la Fiscalía considera indeseable para la comunidad. Quienes resulten condenados por delitos constitutivos de criminalidad organizada transnacional o que atenten contra víctimas de delitos de abuso sexual deberían cumplir penas de cárcel. Primero, porque la expulsión penal no debe ser jamás un privilegio inconstitucional. Segundo, debido a que las víctimas de delitos graves tienen derecho a obtener la tutela judicial efectiva material, a su favor, mediante el castigo real y no únicamente nominal, de los culpables. Tercero, en razón al principio kantiano que prescribe imponer un castigo justo, retributivo y proporcional a la gravedad de la culpabilidad del autor del delito, que hubiese sido probado en el proceso.

3. El ahorro a las arcas fiscales, o el menor gasto presupuestario destinado a mantener el funcionamiento regular de los establecimientos penitenciarios, no debiera ser una razón suficiente para imponer directamente la expulsión de extranjeros que hubieren delinquido en Chile. La legislación española es más criteriosa que la chilena, en razón a que aquella ha establecido expresamente fines preventivo-generales positivos de la pena de expulsión de ciudadanos extranjeros, en su artículo 89 del Código Penal modificado en el año 2015: "cuando resulte necesario para asegurar la defensa del orden jurídico y restablecer la confianza en la vigencia de la norma infringida por el delito". Adherimos en plenitud a una teoría preventiva mixta, que unifica los fines preventivoespeciales y generales de la pena, que ha sido formulada por Claus Roxin. 
4. La legislación chilena está atrasada en relación con el artículo 89 del Código Penal español. En primer lugar, porque es viable aplicar la expulsión penal en Chile a penas de presidio o reclusión inferiores a un año, mientras que en España la pena de prisión debe ser de más de un año. En segundo lugar, los extranjeros con residencia legal caen fuera del campo semántico del artículo 34 de la Ley $n^{\circ} 18.216$ modificada por la Ley $n^{\circ} 20.603$ de 2012. En tercer lugar, la expulsión penal chilena no permite, por una razón de incompatibilidad, imponer la pena privativa de libertad de manera efectiva hasta dos tercios de la extensión, mientras que el artículo 89 del Código Penal español lo autoriza. En cuarto lugar, porque la ley chilena no reconoce el criterio de proporcionalidad, a diferencia de la expulsión prevista en el artículo 89 del Código Penal español. Y en quinto lugar, porque la trata de personas no ha quedado excluida de ser sustituida por la pena de expulsión, en tanto que en España no se permite tal sustitución penal. En Chile parece necesario hacer algunas modificaciones al artículo 34 de la Ley $\mathrm{n}^{\circ} 18.216$ modificada por la Ley $n^{\circ} 20.603$ de 2012, para efectos de adaptar la expulsión penal a los fines de la pena, que correspondan a un Estado democrático de Derecho.

5. La expulsión penal no debe ser un privilegio para el condenado. Tampoco un castigo adicional a la pena privativa de libertad. La doble penalización de un extranjero que ha sido condenado por cometer delito de usura, establecido en el inciso tercero del artículo 472 del Código Penal chileno, a partir de la promulgación de la Ley $n^{\circ} 20.603$, contraviene el principio ne bis in idem del Derecho Penal, porque impone el cumplimiento íntegro de la pena principal, y solo una vez cumplida ésta, ordena la posterior expulsión del sentenciado extranjero del territorio nacional.

\section{BIBLIOGRAFÍA CITADA}

AlbreCHT, Hans-Jörg (2001): Criminalidad transnacional, comercio de narcóticos y lavado de dinero (Bogotá, Universidad Externado de Colombia, Centro de Investigaciones de Derecho Penal).

AlCÁCER, Rafael (2001): Los fines del Derecho Penal. Liberalismo y comunitarismo en la justificación de la pena (Buenos Aires, Ad-Hoc).

Alexy, Robert (1997): Teoría de los Derechos Fundamentales (traducc. Ernesto Garzón Valdés y revisión Ruth Zimmerlinng, Madrid, Centro de Estudios Constitucionales). 
GUTIÉRREZ MOYA, CARLOS: LA EXPULSIÓN COMO PENA CONTRA UN INMIGRANTE: ¿ES UN CASTIGO O UN PREMIO PARA EL CONDENADO EXTRANJERO SIN RESIDENCIA LEGAL?

ARANGO, Juan (1995): "Población y migraciones internacionales", en AAVV: Las Naciones Unidas en la nueva sociedad internacional (Madrid, Fundación Friedrich Ebert) pp. 168 - 197.

Aristóteles (1943): Nicomachean ethics (Trad. James E.C. Welldon, Roslyn, New York, Walter J. Black, Inc.).

AsúA, Adela (2002): "La expulsión del extranjero como alternativa a la pena: incongruencias de la subordinación del Derecho Penal a las políticas de control de la inmigración", Laurenzo Copello, P. (coord.) Inmigración y Derecho penal. Bases para un debate (Valencia, Tirant lo Blanch) pp. 17 - 96.

Berdal, Mats y Serrano, Mónica (coords.) (2005): Crimen transnacional organizado y seguridad internacional, cambio y continuidad (Trad. Isabel Vericat Núñez, México, Fondo de Cultura Económica).

Blanc-Chaléard, Marie-Claude (2000): Historie de l'immigration (Paris, Repères, La Decouvert).

BrandARIZ, José (2008): "La construcción de los migrantes como categoría de riesgo", en Canción Meliá, Manuel y Pizuelo Pérez, Luis (coords.), Política criminal en vanguardia. inmigración clandestina, terrorismo, criminalidad organizada (Cizur Menor-Navarra, Thomson Civitas) pp. 143 - 196.

BuDINICH, Edmundo (2016): Seguridad privada y violencia en los estadios (Santiago, Imprenta gráfica LOM).

Bustos, Juan (1997): "La problemática de las medidas sustitutivas y alternativas", Baigún, David y Zaffaroni, Eugenio, García-Pablos, Antonio y Pierangeli, José (coords.), De las Penas. Homenaje al Profesor Isidoro de Benedetti (Buenos Aires, Depalma) pp. 91 - 97.

CANO, Adoración (2015): "IX Especial consideración de la expulsión de los extranjeros. La sustitución de la pena de prisión por la de expulsión", en González, José (dir), Gorriz, Elena y Metallín, Ángela (coords.), Comentarios a la reforma del Código Penal de 2015 (2ª edición, Valencia, Tirant Lo Blanch) pp. 362 - 374.

CERDA, Rodrigo (2004): Etapa Intermedia, Juicio Oral y Recursos (Santiago de Chile, Librotecnia). 
Defensoría Penal Pública (2014): Penas Sustitutivas Ley 18.216 (Santiago, Documentos oficiales $\mathrm{n}^{\circ} \mathrm{9} /$ diciembre, Centro de Documentación Defensoría Penal Pública), pp. 150-156.

Delbez, Louis (1964): Les príncipes généraux du Droit International Public (3 edición, Paris, Librairie Générale du Droit et Jurisprudence).

Dellacasa, José y Hurtado, José (2015): Derecho migratorio chileno (Santiago, Editorial Jurídica de Chile).

DIDIER, María (2012): El principio de igualdad en la norma jurídica. Estudio de las decisiones de la Corte Suprema argentina y su vinculación en cuestiones de constitucionalidad con la jurisprudencia de la Corte Suprema de Estados Unidos (Marcial Pons, Buenos Aires).

Favarel-Garrigues, Gilles (2002): "La criminalité organisée transnationale: un concept à enterrer", L' économie politique $\mathrm{n}^{\circ}$ 15: pp. 8 - 22.

García, Mercedes (coord.) (2006): Trata de personas y explotación sexual (Granada, Comares).

Hassemer, Winfried (2003): Crítica al Derecho Penal de Hoy. Norma, Interpretación, Procedimiento, Límites a la prisión preventiva ( $2^{a}$ edición, Trad. Patricia S. Ziffer, Buenos Aires, Ad-Hoc).

IGLESIAS, Agustina (2014): La trata de mujeres con fines de explotación sexual (Buenos Aires, Ediciones Didot).

Jakobs, Günther (1997): Derecho Penal. Parte General. Fundamentos y teoría de la imputación ( $2^{a}$ edición, Trad. Joaquín Cuello Contreras y José Luis Serrano González de Murillo, Madrid, Marcial Pons).

KANT, Immanuel (1911): Metaphysik der Sitten (Berlín, Real Academia Prusiana de las Ciencias).

Kaufmann, Arthur (1999): Filosofía del Derecho (Trad. Luis Villar Borda y Ana María Montoya, Bogotá, Universidad Externado de Colombia).

MACKenZIE, Caroline (2005): "Diversidad, pluralidad e identidades. Capítulo 8", en Arnaud Blin et. al., Cien proposiciones del Foro Social Mundial Porto Alegre (Madrid, Colección 0 a la Izquierda, Editorial Popular) pp. 149 -167. 
GUTIÉRREZ MOYA, CARLOS: LA EXPULSIÓN COMO PENA CONTRA UN INMIGRANTE: ¿ES UN CASTIGO O UN PREMIO PARA EL CONDENADO EXTRANJERO SIN RESIDENCIA LEGAL?

MAYER, Julio (1997): "El ofendido por el delito en el Derecho positivo argentino", en Baigún, David y Zaffaroni, Eugenio, García-Pablos, Antonio y Pierangeli, José (coords.), De las Penas. Homenaje al Profesor Isidoro de Benedetti (Buenos Aires, Depalma) pp. 305 - 348.

MIR, Santiago (2011): Derecho Penal. Parte General (9ª edición, BarcelonaMontevideo-Buenos Aires, Julio César Faira, Editor).

Molina, María y Molina, Luis (2008): El Blanqueo de Dinero (Barcelona, Bosch).

Monclús, Marta y Brandariz, José (2015): Políticas y prácticas de control migratorio. Estudio comparativo del control de los migrantes en los contextos latinoamericano y europeo (Buenos Aires, Ediciones Didot).

Nieva, Jordi (2014): Introducción al Derecho Procesal I (Barcelona, Marcial Pons).

Pérez, Ana (2006): "El Código Penal de la seguridad: una involución de la política criminal reaccionaria", en Bernuz, María y Pérez, Ana, Coordinadores. La tensión entre liberalismo y seguridad. Una aproximación sociojurídica (Logroño, Universidad La Rioja).

Politoff, Sergio, Matus, Jean Pierre y Ramírez, María (2007): Lecciones de Derecho Penal Chileno. Parte especial ( $2^{a}$ edición, Santiago, Editorial Jurídica de Chile).

RAMONET, Ignacio (2002): "Voyages sans retour", Manière de voir 62 Histoire(s) d'inmmigration (Paris, Le Monde diplomatique), pp. 6-7.

Robert, Anne-Cécile (2002): "De Schengen à Amsterdam", Manière de voir 62 Histoire(s) d'inmmigration (Paris, Le Monde diplomatique) p. 80.

Rodney, Benson (2015): "Quarante ans d'immigration dans les médias enquête en France et aux Etats-Unis" Manière de voir 62 Histoire(s) d'inmmigration (Paris, Le Monde diplomatique) pp. 10-11.

RodríGuez, Luis (2000): La detención (Madrid, Akal).

RompaO, Kira (2016): "Condena por delito y expulsión: La expulsión penal (I)", 3 p. Disponible en <http://www.kirarompao.es/blog/12-penal/41-condena-por-delito-y-expulsion-i>, fecha de consulta: 9 de diciembre 2016. 
Roxin, Claus (2001): Derecho Penal. Parte General. Tomo I. Fundamentos de la estructura de la teoría del delito ( $2^{\text {a }}$ edición, Trad. D-M. Luzón Peña/M. Díaz y García Conlledo/J. de Vicente Remesal, Madrid, Civitas).

Salinero, Sebastián (2011): "La expulsión de extranjeros en el Derecho penal. Una realidad en España, una posibilidad en Chile", pp. 106 141. Disponible en <http://www.politicacriminal.cl/Vol_06/n_11/ Vol6N11A4.pdf>, fecha de consulta: 9 diciembre 2016.

Sanz, Nieves (2008): Sistema de sanciones en España y Chile. Alternativas a la prisión (Santiago, Universidad Andrés Bello/EVE).

Sorensen, Max (2008): Manual de Derecho Internacional Público (Trad. Dotación Carnegie para la Paz Internacional, México, Fondo de Cultura Económica).

Unidad de Defensa Penal Juvenil y Defensas Especializadas (2015): Tercer Informe Jurisprudencia Defensa de Migrantes y Extranjeros, Departamento de Estudios y Proyectos, Noviembre (Santiago, Ediciones Defensoría Penal Pública).

Welzel, Hans (1993): Derecho Penal alemán, parte general (4ª edición, trad. Juan Bustos Ramírez y Sergio Yáñez Pérez, Santiago, Editorial Jurídica de Chile).

\section{NORMAS JURÍDICAS CITADAS}

Código Penal de 12 de noviembre de 1874 (Chile).

Código Penal de 24 de noviembre de 1995 (España).

Constitución Política de la República de Chile del 11 de marzo de 1980.

Convención Americana sobre Derechos Humanos, de la Organización de Estados Americanos del 22 de noviembre de 1969.

Convención de Ginebra, sobre el Estatuto de los Refugiados, del Alto Comisionado para las Naciones Unidas del 28 de julio de 1951.

Convención de Viena sobre el Derecho de los Tratados, de Naciones Unidas del 23 de mayo de 1969.

Convención de Viena sobre Relaciones Diplomáticas, de Naciones Unidas del 18 de abril de 1961. 
GUTIÉRREZ MOYA, CARLOS: LA EXPULSIÓN COMO PENA CONTRA UN INMIGRANTE: ¿ES UN CASTIGO O UN PREMIO PARA EL CONDENADO EXTRANJERO SIN RESIDENCIA LEGAL?

Decreto Ley $n^{\circ} 1.094$ del 19 de julio de 1975, Establece normas sobre extranjeros en Chile.

Decreto Ley $\mathrm{n}^{\circ} 400$ del 13 de abril de 1978, Fija texto refundido, coordinado y sistematizado de la Ley $n^{\circ} 17.798$, sobre Control de Armas, modificada por la Ley $n^{\circ} 20.813$ del 6 de febrero de 2015 (Chile).

Ley 1/2015 de 30 de marzo de 2015, Modifica el artículo 39 del Código Penal (España).

Ley $n^{\circ} 7.421$ del 9 de julio de 1943, Código Orgánico de Tribunales (Chile).

Ley $\mathrm{n}^{\circ} 18.216$ del 14 de mayo de 1983, Establece penas que indica como sustitutivas a las penas privativas o restrictivas de libertad, modificada por la Ley n² 20.603 del 27 de junio de 2012. (Chile)

Ley nº 19.696 del 12 de octubre de 2000, Código Procesal Penal (Chile).

Ley $\mathrm{n}^{\circ} 20.084$ del 7 de diciembre de 2005, Establece un sistema de responsabilidad de los adolescentes por infracciones a la ley penal (Chile).

Ley $\mathrm{n}^{\circ} 20.603$ de 2012, establece un catálogo de penas sustitutivas, de fecha 27 de junio de 2012 (Chile).

Ley $\mathrm{n}^{\circ} 25.871$ del 21 de enero de 2004, Ley de Migraciones (Argentina)

\section{JURISPRUDENCIA CITADA}

Corte de Apelaciones de San Miguel, A favor de I.G.G. y O.S.C. (2013): 6 de diciembre de 2013, rol n² 295-2013, recurso de amparo.

Corte Suprema, A favor de Y.M.Z. (2015): 3 de mayo de 2016, rol $\mathrm{n}^{\circ}$ 8726-2015, recurso de amparo. Disponible en: <http://suprema.poderjudicial.cl/SITSUPPORWEB/DownloadFile.do?TIP_ Documento $=3 \&$ TIP_Archivo=1\&COD_Opcion $=1 \&$ COD_ Corte $=1 \&$ CRR_IdTramite $=1689469 \&$ CRR_IdDocumento $=1230041>$, fecha de consulta: 7 de abril de 2017.

Corte Suprema Federal (Estados Unidos), Bernal v. Fainter, 467 U.S. 216 (1984).

$5^{\circ}$ Juzgado de Garantía de Santiago, Ministerio Público contra M.A.B.S. (2016): R.U.C. $n^{\circ} 1500184146-4$, R.I.T. n 907-2015. 